\title{
ICE E-FERRY CONCEPT DESIGN, AN INNOVATIVE ZERO-EMISSION SOLUTION FOR MEDIUM RANGE CONNECTIONS
}

\author{
Dumitru Negoita \\ ICEPRONAV ENGINEERING SRL \\ Portului Street, No. 19A, \\ Galati, Romania, \\ E-mail:dumitru.negoita@icepronav.ro
}

\author{
Cristian Antache \\ ICEPRONAV ENGINEERING SRL, \\ Portului Street, No. 19A, \\ Galati, Romania, \\ E-mail:cristian.antache@ icepronav.ro
}

\begin{abstract}
This paper outlines the concept design developed by International Contract Engineering (ICE) for an all-electric double-ended ferry designed for a medium range crossing (about 8 nautical miles). The international market of hybrid and all-electric ferries is highlighted with related advantages and barriers, and some statistics, in the context of the new environmental international rules (summarised in the paper).
\end{abstract}

Keywords: ferry, battery, lithium-ion, hybrid, shore charging, environmental rules, emissions.

\section{INTRODUCTION}

Many companies feel a pressure to reduce its carbon footprint and invest in technology that limits emissions and improves resource efficiency. The public increasingly see air pollution and climate change as being interconnected. Ports, coastal cities and their local communities are the most vulnerable to extreme weather conditions resulting from them.

Global shipping is one of the largest energy consumer and carbon emitter after road passenger and commercial vehicles. Maritime transport emits around 940 million tonnes of $\mathrm{CO} 2$ annually and is responsible for about $2.5 \%$ of global greenhouse gas (GHG) emissions; the amount of emission could increase between $50 \%$ and $250 \%$ by 2050 if mitigation measures are not put in place swiftly (3rd IMO GHG study).

In the area of maritime transportation, the IMO (International Maritime Organization) has been introducing new and stricter regulations since 2003, with MARPOL An- nex IV on the Prevention of Air Pollution from Ships aiming to reduce NOx, SOx and $\mathrm{CO} 2$ levels, as is detailed below.

\subsection{NOx emission limits}

They were set by the IMO for diesel engines against the engine maximum operating speed (n [rpm]) as jointly shown in Table and Figure below. It should be mentioned that Tier III level is only applied in emission control areas (ECAs) whilst Tier I and Tier II are in force globally.

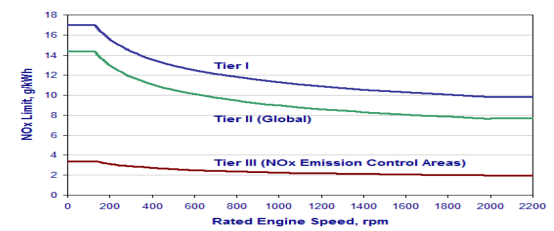

Fig.1. NOx emission limits according to MARPOL Annex VI (IMO, 2017)

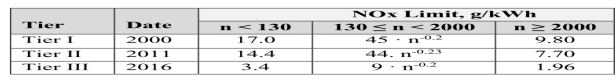


Fig.2. MARPOL Annex VI NOx Emission Limits (IMO, 2017)

\section{SOx emission limits}

The IMO has set limitations on sulphur content in the fuel in the MARPOL Annex VI standards (see Fig. 3 below).

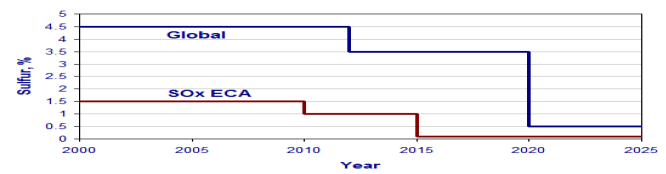

Fig.3. Fuel sulphur limits according to MARPOL Annex VI (IMO, 2014)

\section{2 $\mathrm{CO}_{2}$ emissions limits}

The IMO has intended to improve the shipping sectors' carbon footprint by introducing the Energy Efficiency Design Index (EEDI), the Energy Efficiency Operational Indicator (EEOI) and Ship Energy Efficiency Management Plan (SEEMP). The EEDI was made mandatory for new ships and its standards will be tightened every 5 years from 2015 to 2030 as detailed in Figure below.

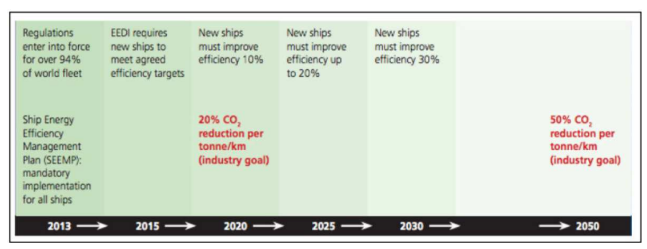

Fig.4. EEDI: MARPOL Annex VI, CO2 Limits (IMO, 2012, ICS, 2014)

The above indicated reduction of harmful gas emissions is expected to impact fuel prices (mainly due to using of low surfur content fuels, which are more expensive than fuel commonly used until now), implying additional cost for shipping. These emission limitations have forced the shipping industry to search for alternative ecological solutions for their ships.

\section{ALL-ELECTRIC FERRY HIGHLIGHTS}

\subsection{Status of the hybrid-battery and all- battery ferry market}

In the context of emission limitations requirements indicated in the previous chapter, some sectors of the ferry market seems to be the most advanced in implementing "greener" solutions, the preferred solutions being either hybrid ferries (with diesel engines and battery banks) or all-electric (using battery- only) ferries.

The hybrid-battery ferries are using both diesel generators and battery banks for propulsion (e.g. they can use the battery banks for zero-emissions propulsion in the harbor area and the diesel generators for the rest of the voyage), while all-electric battery ferries are using only the battery banks for propulsion.

Some examples of ferry companies which started the green shift are indicated below; most of them are from Norway, the first country in the world to adopt legislation which declare its UNESCO World Heritage fjords as zero-emmision areas for ships, becoming effective in 2026 at the latest.

Fjord1, the largest ferry company in Norway, has currently a fleet of 89 ships, 13 of them being newly built all electric ferries; by 2020 Fjord 1 will have 29 electric vessels in operation (either newly built or converted hybrid-electric ferries), which means about $30 \%$ of the fleet.

Norled, another major ferry company in Norway, which operated the world's first allelectric ferry (Ampere, delivered in 2015), has a fleet of 80 ships, 13 of them being newly built or converted hybrid-battery or all electric ferries. This company has recently won a contract to introduce the world's first hydrogen-powered ferry concept, which will come into operation in 2021.

Scandlines, a Denmark/Germany large ferry company, has 6 of 8 ferries in hybridbattery technology, with the plan to operate 
in the next future all-electric ferries on a $18.5 \mathrm{~km}$ route.

CalMac Ferries Ltd, an important Scotland ferry company has 3 of 36 ferries using hybrid-battery technology.

Stena Line is a Swedish large ferry company with one hybrid-battery ferry (its fleet has about 35 ships).

The Ministry of Transportation of Ontario will operate two all-electric ferries in Canada from 2020/2021.

HMS Ferries is operating its first allelectric ferry in the United States since 2019, a conversion of a conventional diesel propulsed ferry.

The municipality of Aeroe in Denmark is operating since 2019 the all-battery ferry with the world's largest battery bank (of 4.3MWh), Ellen, with 198 passengers and 31 car- capacity, which crosses distances up to 22 nautical miles $(38 \mathrm{~km})$.

\subsection{Status of class rules for hybrid-battery and all-electric ships}

The first classification society which created class rules for all-electric and hybridelectric ships is DNV-GL, effective from 2012. Currently they have the additional class notation Battery (Safety) for the hybrid-electric ships, and Battery (Power) for the all-electric ships. DNV-GL has 94 battery-powered vessels in its classification register, and the major lithium-ion battery manufacturers for marine systems have product certificates with DNV-GL.

In 2014 the DNV-GL, Norwegian Maritime Autority (NMA) and others firms founded the Maritime Battery Forum (https://maritimebatteryforum.com), a meeting place for equipment manufacturers and ship owners interested in new hybrid and electric technology. Two recent statistics provided by this forum highlight the number of ships with batteries in operation and under construction (Fig. 5), and the number of ships with batteries by ship type (Fig. 6).

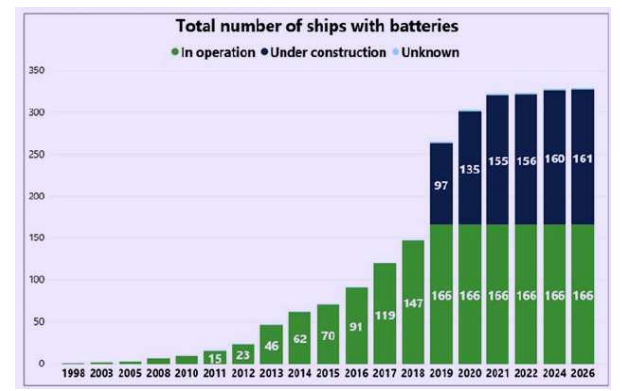

Fig.5. Total number of ships with batteries Marine Battery Forum

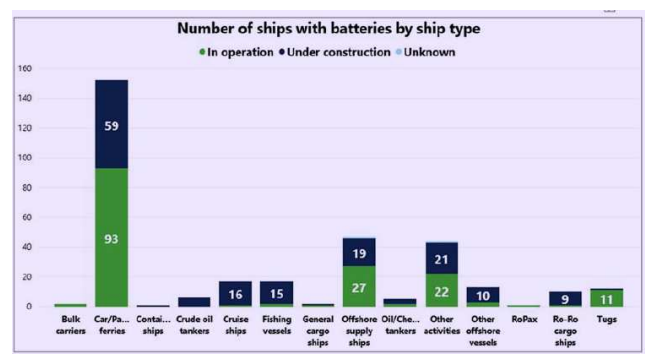

Fig.6. Number of ships with batteries by ship type - Marine Battery Forum

\section{ADVANTAGES AND BARRIERS FOR FERRIES ELECTRIFICATION}

The main advantages of hybrid-battery and all-battery ferries are highlighted below.

\subsection{Hybrid-battery ferries}

The hybrid-battery ferries are usually converted from conventional diesel-electric ferries, by replacing a diesel generator with a battery bank. By using the battery simultaneously with the diesel engines, the engines are working at the optimum level of load which is $85-90 \%$, saving fuel and reducing emmisions. When the propulsion electric motors needs more energy than the diesel generator can supply, it uses in addition the batteries' energy - and when there is less need for energy, excess energy is saved in the batteries see Fig. 7 below. In the harbor area the ferry can navigate fully on batteries, with zeroemissions. 
The battery banks can be charged either by diesel generators or from shore charging stations.

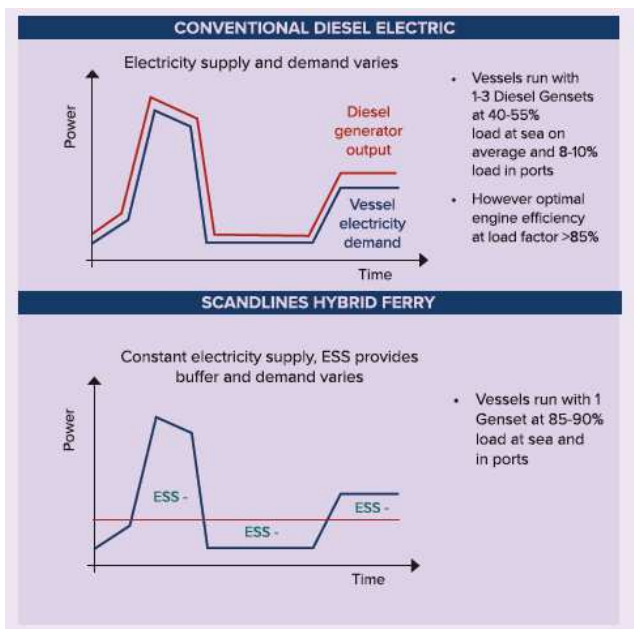

Fig.7. Hybrid energy meets variable energy demand - RMI, Case study Scandlines ferries - hybrid retrofit, 2016

An example of environmental savings for this kind of ferry is the large hybrid ferries operated by Scandlines, with capacity of 1300 passengers and 460 cars.By introducing an $1.5 \mathrm{MWh}$ battery bank the company recorded $10-15 \%$ fuel and carbon emission savings, resulting in a five-year pay-back period (RMI, Case study Scandlines ferries hybrid retrofit, 2016).

Briefly, the advantages of hybrid-battery technology are: fuel and $\mathrm{CO} 2$ emission reductions by operating diesel engines at their optimal efficiency, reduced engine running hours and, as concequence, reduced maintenance for them. The main barrier is high cost of initial investment, but as it is indicated in the study case, this cost can be recovered in about 5 years.

\subsection{All-electric ferries}

In the case of all-electric ships, the power for propulsion and other consumers are provided only by the battery banks. Because the ferries are relative small ships, which travel short distances and operate along regular routes and schedules, they are highly amenable to full electric power trains.

The last environmental regulations and the last development of technology for lithium-ion batteries combined with increased hydrocarbon fuel price were the main catalysts for increased implementation of allelectric ferry technology.

The main advantages of using allelectric ferries are:

- lower cost of operation due to reduced crew and lower cost of shore electricity than the cost of electricity produced onboard by diesel generator (e.g. the Ampere ferry runs on fossil-free energy at costs $60 \%$ lower than with regular diesel because onshore electricity used for battery charging is supplied entirely by hydropower (Northvolt, 2019);

- payback period of about 5.5 years as per a research study conducted by Siemens in 2016;

- zero-emissions of harmful gases, with the possibility for shore charging stations to use electricity produced mainly from regenerable sources (wind, water, solar, etc) - a successful green solution in Norway;

- improved confort for passengers due to reduced noise and vibrations;

- increased robustness against increases in fuel prices and changes to stricter environmental regulations;

- no hydrocarbon fuel onboard and reduced crew/maintenance as result of removing the diesel engines;

- improved redundancy/safety by splitting the battery bank and electrical distribution in two parts, installed in separate compartments;

- very few issues with cells from the leading producers are reported; 
- the prices of lithium-ion batteries are expected to decrease in the near future.

The main disadvantages/barriers for the implementation of all-electric ferry technology are the following:

- a cost of about $40 \%$ more than traditional ferry, each prototype eferry usualy being co-financed by the European Union or national governments;

- present legislation related to energy taxes, e.g. hydrocarbon fuels for ships are exempted from all taxes in many European countries, while the electrical energy is heavily taxed;

- the shore charging at very high power rate involves special requirements for shore electrical grid (availability of the power rate required by shore charging station; infrastructure necessary for shore charging station - HV/LV transformer, switchboard with battery converter and buffer battery bank, if needed, plug or pantograph electrical power connection, shore vacuum-based mooring station);

- the challenge to ensure high power rate charging in a safe way in all weather and operational conditions (some "teething problems" have been reported);

- limited life cycles of batteries, and the heavy weight of batteries, which may have to be compensated by using different materials for the ships superstructure (e.g. aluminium or lightweight carbon composite materials);

- fully electrical operation requires different crew competences.
The lithium-ion technology for rechargeable batteries has become the most promising and fast growing on the market. For marine applications there are used mainly the Li-ion cells with NMC (Nickel Manganese Cobalt Oxide) cathodes and graphite anodes, which provide a good compromise between the following parameters: safety, energy, power density, life cycle and cost (high energy density, improved cycle life, moderate discharge current, no maintenance required, no toxicity, relatively high cost). In addition, by using polymer electrolyte, the attributes of the $\mathrm{Li}$ ion batteries can be had in ultra-slim geometry and simplified packaging.Fig.8 below presents a comparison between traditional lead acid batteries and Lithiumion batteries (Hybrid ferries project, IET CMAL, 2012).

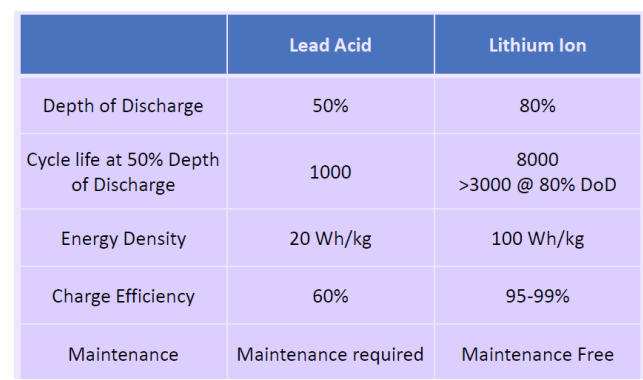

Fig.8. Comparison between lead acid batteries and lithium-ion batteries (IET CMAL, Hybrid Ferries Project, 2012)

The development of cost of lithium-ion batteries during $2010-2018$ is indicated in Fig. 9; the cost is expected to continue to decrease in the next years.

\section{LITHIUM-ION BATTERIES. SHIP DC POWER GRID - HIGHLIGHTS}

\subsection{Lithium-ion batteries}


Lithium-ion battery price survey results: volume-weighted average Battery pack price (real $2018 \$ / \mathrm{kWh})$

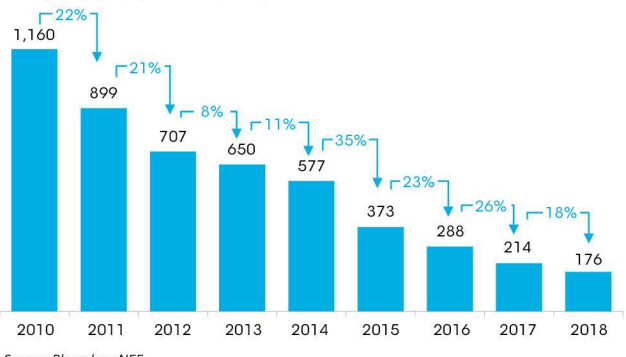

Fig.9. Lithium-ion batteries price evolution $2010-2018$

The main manufacturers of lithium-ion batteries for marine market are: Corvus Energy, Plan B Energy Storage (PBES), Siemens, Leclanche, and Spear Power Systems. For ships the supplier will normally deliver a complete Energy Storage System (ESS), which include both the battery bank and the battery management system (BMS) with the functions required by classification societies.

\subsection{DC power grid for ferries}

Due to the fact that the main power source for all-electric ferries are the battery banks, the use of main switchboards with DC bus bars became the natural choice. The converters for batteries banks charging and the $\mathrm{DC} / \mathrm{AC}$ inverters for power supplying the main electrical consumers (in alternating current) are usually integrated in these switchboards.

Some of the main manufacturers of DC main switchboards are Siemens (with BlueDrive PlusC), ABB (with Onboard DC Grid concept) and NES (Norvegian Electric Systems).

\section{ICE E-FERRY CONCEPT DESIGN}

As part of a new ferry service planned by an undisclosed client, ICE developed a concept design for an all-electric double ended ferry, as highlighted in the next paragraphs.

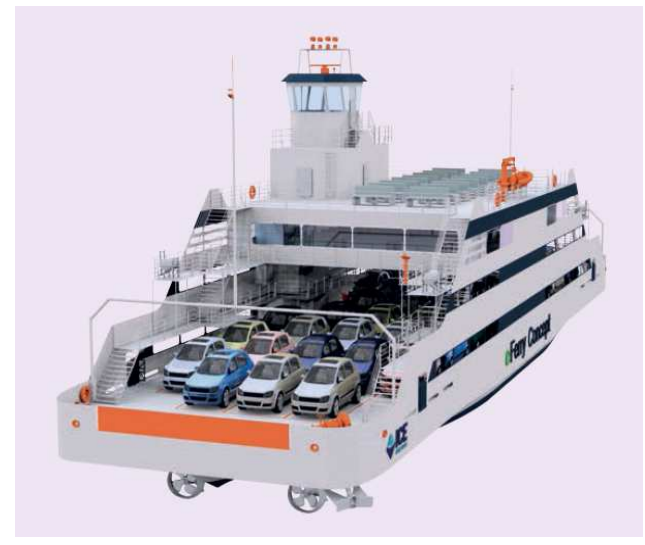

Fig.10. ICE eFerry 3D view

\subsection{Main characteristics}

The ferry's main characteristics are listed below.Fig. 5 presents the general arrangement of the ship.
Main Dimensions
Length overall. $.60 \mathrm{~m}$
Length between perpendiculars.......57.4m
Breadth moulded.....................15m
Depth moulded......................4.5m
Draught, summer.................. $2.3 \mathrm{~m}$

\section{Capacities}

Fresh water (fire fighting)............10.2 $\mathrm{m}^{3}$

Fresh water (sanitary)................ $8.5 \mathrm{~m}^{3}$

Grey/black water tank............... $17 \mathrm{~m}^{3}$

Bilge tank............................ $2.3 \mathrm{~m}^{3}$

Heeling/ballast tanks (x2)...........40m ${ }^{3}$

Car deck

Car deck area........................600m ${ }^{2}$

Number of cars........................45

Crew and passenger facilities

PAX..................................200

Crew.................................4

Accessability for disabled persons

Speed

Speed, max $15 \mathrm{knots}$ 
Propulsion system

Azimuth thrusters (x4) $.750 \mathrm{~kW}$

Electrical plant

Installed battery capacity. $.3660 \mathrm{kWh}$

\subsection{Key design features}

The ferry's main design benefits are highlighted below.

\section{- Autonomy}

The ship is sized to serve medium range crossings, sailing $100 \%$ on batteries up to 8 nautical miles $(14.8 \mathrm{~km})$ with a maximum speed of 15 knots $(27.8 \mathrm{~km} / \mathrm{h})$ in waters where significant wave height is not expected to exceed 2 meters at any time. Almost all electric ferries in operation are working on short range ferry crossings.

\section{- Battery banks}

The ship has as main source of power two lithium-ion battery banks of $1830 \mathrm{kWh}$ each, arranged in separate battery rooms for redundancy purpose, as required by the classification society rules (e.g. DNV GL Rules for classification Ships, Part 6, Chapter 2, Section 1, July 2018). The batteries shall be provided with a battery management system, with control, monitoring and protective function of the battery system, as per classification society requirements. Mainly the system provides limits for charging and discharging to the battery converter; protects against over-current, over-voltage and under-voltage; protect against over-temperature; provide cell and module balancing.

In principle, the size of battery banks was dictated by:

- Ferry's electrical power consumptions (propellers + others consummers);

- Operational profile of the ship (the timing table of the ferries to operate the route, with times of sailing / at terminals). For the ICE concept it was considered the following profile for the ferry: $40 \mathrm{~min}$. of sailing, $20 \mathrm{~min}$. docking (with $18 \mathrm{~min}$. of charging), and 1 hour charging at berth after each 6 crossing (i.e. 3 round trips).

- The ferry terminals' facilities for battery bank charging (the maximum charging rate which can be provided by local electrical grid; if it is inadequate there may be a need for terminal buffer battery banks);

- Maximum Depth of Discharge (DoD) considered for the ferry battery banks and for the ferry terminal buffer battery bank (if any). For the ICE concept the maximum DoD was considered $60 \%$.

Battery rooms are provided with temperature and ventilation monitoring, and marine clean agent fire suppression system, as required by classification societies rules. In the ICE concept it was assumed that battery rooms are non-hazardous areas, the class accepting this room classification based on a safety description which presents the hazards and the means to mitigate the identified risks.

A typical battery room for an all electric ship is shown in the Fig. 11 below.

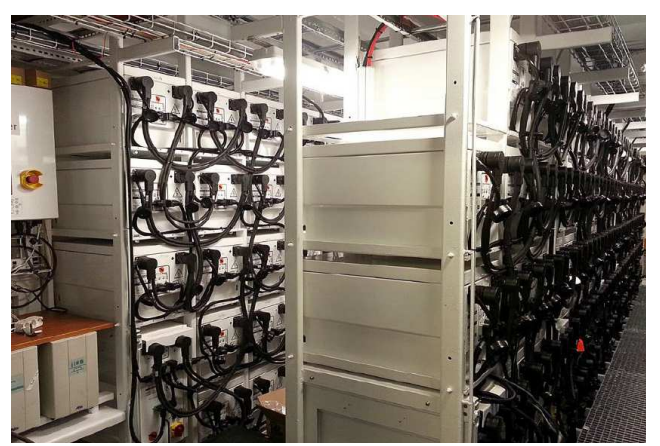

Fig.11. Typical battery room arrangement for an electric ship

\section{- Manouvrability}

The ship has an improved maneuverability assured by four azimuth electrically-driven thrusters, two at each end; they are reducing the time spend by ship in manouvring mode, 
which is a benefit for the battery banks capacity (by keeping it lower).

\section{- General arrangement}

The general arrangement of the Roll-on/Rolloff (RO-RO) type ferry, with boarding ramps at both ends, is indicated in the Fig. 12. A practical arrangement with all cars on one deck, with good overview for passengers and crew, is provided. An observation deck with passenger lounge and a sun deck are provided for passengers, and as well a wheelhouse on the top of accommodation.

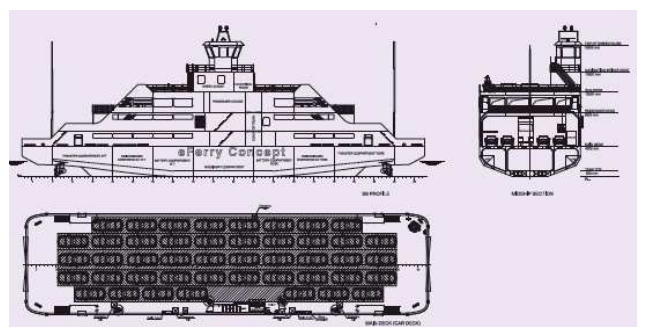

Fig.12. General arrangement for ICE e-ferry

The entire space between the double-bottoms and the main deck shall be used to accommodate machinery compartment, battery compartments, switchboard compartments, thruster compartments and the fore and aft peaks, located symmetrically in relation to the midship. The hull is partitioned with transversal watertight bulkheads to insure compliance with regulations regarding protection in case of damage of any one (1) of the main compartments anywhere in the length between main transverse watertight bulkheads.

- Electrical shore supply system Each shore charging station shall provide $2750 \mathrm{KW}$ output power (at $690 \mathrm{~V} / 50 \mathrm{~Hz}$ ) to the ferry battery converters for quick charging during passengers/cars unloading/loading at terminal. Each shore charging station shall have a plug type and a pantograph type connection with ferry for battery charging see Fig. 13 below an example used for the Ampere ferry. The pantograph system is preferred because it is faster to connect and allows for more motion of the ferry when docked. On the plug system the operator has to wait for the arm to extend and lower the plug. Also the plug does not have much flexibility so if the vessel rocks the plug come loose, interrupting the charge and damaging the contacts.

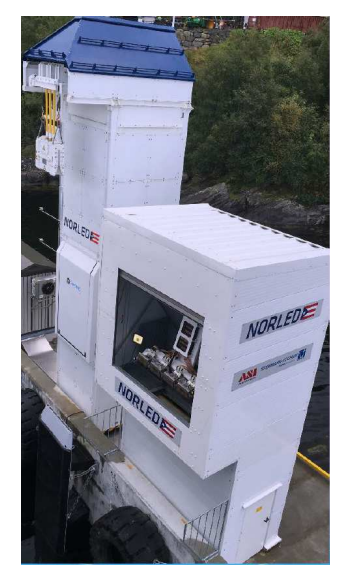

Fig.13. Example of plug type (left side) and pantograph type (right side) shore connection - Ampere ferry

The ferry has two battery converters, for redundancy purposes; normally a battery convertor is charging both battery banks, the bus tie breakers between the DC main switchboards bus bars being closed.

\section{- Ship's electrical distribution system}

The ICE electrical ferry will have two main switchboards with $900 \mathrm{Vdc}$ bus bar voltage, arranged in separate rooms, and connected by bus tie breakers normally closed during ferry sailing and charging at terminals.

The $690 \mathrm{~V} / 50 \mathrm{~Hz}$ main consumers such as thruster motors, HPUs for steering, MCCs for pumps \& fans and transformers for $230 \mathrm{~V} / 50 \mathrm{~Hz}$ distribution net, are power supplied from the $900 \mathrm{Vdc}$ main switchboards via DC/AC inverters suitable rated. These inverters and the ferry battery converters are 
considered integrated in the main switchboards.

The $230 \mathrm{~V} / 50 \mathrm{~Hz}$ distribution net is used for power supply for the lighting, heaters, small fans, navigation and communication equipment, automation equipment, etc.

An example of DC main switchboard described above used currently on the market is BlueDrive PlusC by Siemens, indicated in Fig. 14 below.

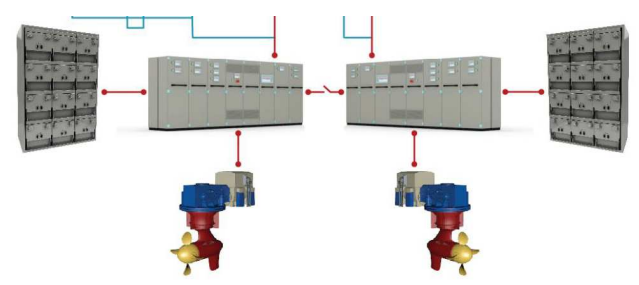

Fig.14. BlueDrive PlusC by Siemens - DC main switchboards for all electric ships

An energy management system with the functions integrated in the ship's power management system was considered in design, in line with the classification societies requirements. The system will measure the available energy and power taking into consideration the batteries $\mathrm{SoH}$ and $\mathrm{SoC}$, and is designed to keep the battery temperatures in the operational limits by limiting the maximum charge and discharge current rates; the maximum and minimum battery voltages (see DNV, etc).

The ferry's energy management system also extends to the shore charging stations, using data radio links.

\section{- Vacuum-based mooring system}

A vacuum-based mooring system will be installed onshore, to pull the vessel against the quay with a suction force of 20 tonnes. Compared to conventional mooring, the vacuum mooring system moor and release the vessel without the vessel using its propellers, which reduces the drain on the battery banks and also reduces the need for crew onboard and/or at the terminal. An example of this type of mooring system currently used on the market is Cavotec MoorMaster, indicated in Fig. 15 below.

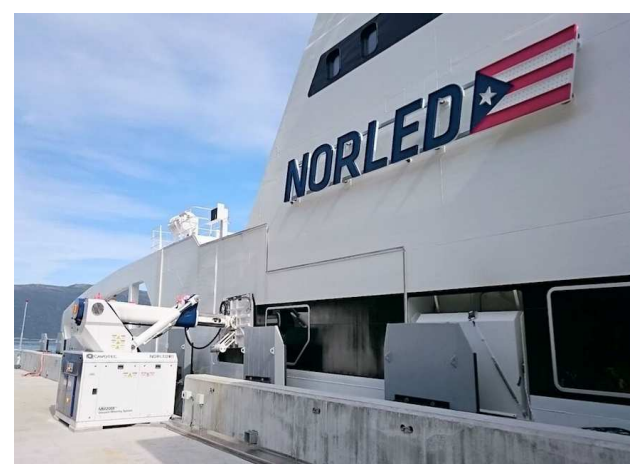

Fig.15. Vacuum based mooring system Cavotec MoorMaster

\section{CONCLUDING REMARKS}

In the international context of NOx, SOx, $\mathrm{CO} 2$ and particulate matter emissions limitations for ships imposed by International Maritime Organisation (IMO), the hybridbattery and all-electric ships represents an important option, favoured by the last developments and cost reductions on the lithiumion batteries market.

Due to their specificities (relative small size, short and medium range voyages, operation along regular routes and schedules, navigation mainly in emissions controlled areas) the ferry market is the most advanced in implementation of above mentioned technologies, currently being in operation or under construction worldwide more than 150 hybridbatteries or all electric ferries car/passenger ferries.

The ICE e-ferry concept presented in this paper is consistent with this trend. This Paper has highlighted the main technical characteristics of the ferry, pointing out the specific matters and the typical benefits for all- 
electric ferries: emission-free technology, higher comfort for passengers by reducing vibrations and noise onboard, reduced maintenance due to not having diesel engines with auxiliaries, improved redundancy, no hazardous hydrocarbon fuel onboard, no requirement for providing emergency diesel generator on board, and lower operations cost than traditional ferries.

\section{Acknowledgements}

The concept of the fully electric battery powered passenger and car ferry is open to design variations and can be adapted to specific customer requirements.

ICE Marine Design Group retains ownership of all the associated Intellectual Property Rights of the described ferry.

\section{REFERENCES}

[1]. International Maritime Organization (IMO), "International Convention for the Prevention of Pollution from Ships MARPOL consolided edition 2017”, Annex VI Prevention of air pollution from ships, pp 281-297, 2017.
[2]. International Maritime Organization (IMO), "Third IMO Greenhouse Gas Study 2014”, pp 18-22, 2015.

[3]. Rocky Mountain Institute (RMI), "Case study: Scandlines Ferries - Hybrid retrofit”, pp 1-2, July 2016.

[4]. The Institution of Engineering and Technology (IET) - Caledonian Maritime Assets Ltd (CMAL), "Hybrid Ferries Project Presentation”, pp 46, 2012.

[5]. DNV-GL, "Guideline for large maritime systems", 2014.

[6]. DNV-GL, "Rules for classification ships, Part 6, Chapter 2, Section 1", pp 14-33, 2018.

[7]. Siemens, "Electric ferries - a study of potentials: Electrification of Denmark's ferry fleet", pp 11, October, 2016.

[8]. Northvolt, "A revolution at sea - the challenges and opportunities of electrifying marine industries", August 8, 2019.

Paper received on November $11^{\text {th }}, 2019$ 